Transactions of the American Fisheries Society, 1992, v.121, n.4, p.494-507

ISSN: (Print 0002-8487) (Online 1548-8659)

doi: 10.1577/1548-8659(1992)121<0494:FCBLGS>2.3.CO;2

http://www.fisheries.org

http://afsjournals.org/loi/fitr

http://afsjournals.org/doi/pdf/10.1577/1548-8659\%281992\%29121\%3C0494\%3AFCBLGS\%3E2.3.CO\%3B2

(C) 1992 American Fisheries Society 


\title{
Food Consumption by Larval Gizzard Shad: Zooplankton Effects and Implications for Reservoir Communities
}

\author{
John M. DetTMers ANd Roy A. STEIN \\ Aquatic Ecology Laboratory, Department of Zoology \\ The Ohio State University. Columbus, Ohio 43210, USA
}

\begin{abstract}
Because peak abundance of larval gizzard shad Dorosoma cepedianum occurs simultaneously with the midsummer decline of macrozooplankton in Ohio reservoirs, we hypothesized that zooplanktivory by larval gizzard shad caused this decline. To test this hypothesis, we compared larval food consumption with zooplankton productivity in two reservoirs. Larval gizzard shad began to influence zooplankton production in a reservoir with high zooplankton productivity (exceeding $125 \mathrm{mg} \cdot \mathrm{m}^{3} \cdot \mathrm{d}^{-1}$ ) only after peak zooplankton biomass occurred, even at high larval densities ( 38 shad $\left.\cdot \mathrm{m}^{-3}\right)$. However, consumption by early juvenile $(25-30-\mathrm{mm}$ ) gizzard shad severely reduced zooplankton in this reservoir. Conversely, relatively low densities of larval gizzard shad (3-7 shad $\cdot \mathrm{m}^{-3}$ ) had variable effects on zooplankton in a reservoir with low zooplankton productivity (at most $4 \mathrm{mg} \cdot \mathrm{m}^{-3} \cdot \mathrm{d}^{-1}$ ). Depending on larval gizzard shad density and zooplankton production, larval gizzard shad alone or in conjunction with early juveniles may control zooplankton assemblages, increasing competition for limited resources at a time when zooplankton are critical to sport-fish recruitment.
\end{abstract}

Predation often influences community structure (O'Brien 1987). Aquatic systems tend to be less structurally complex than terrestrial ecosystems, affording prey fewer refugia than their terrestrial counterparts (Murdoch and Bence 1987). As a result, aquatic communities may be strongly mediated by predation. Competition in aquatic communities also is common and may arise from size-structured interactions where similar-sized individuals of different species compete for a limited resource (Stein et al. 1988). Predation by a particularly numerous or efficient species may directly influence the competitive interactions among its prey or with competitors at its trophic level. Two species that interact as predator and prey as adults may be competitors as larvae or juveniles. These mixed predation-competition interactions may play an important role in aquatic communities.

Gizzard shad Dorosoma cepedianum are abundant in many reservoirs throughout the southeastern USA, often dominating the fish community (Cramer and Marzolf 1970; Noble 1981; Johnson et al. 1988). As preferred prey for many piscivores (Carline et al. 1986; Johnson et al. 1988; Matthews et al. 1988; Wahl and Stein 1988), they have been stocked in attempts to improve predator growth rates (Noble 1981). Historically, however, little effort has been directed toward quantifying the role of gizzard shad in freshwater systems and the possible direct and indirect effects of this species on aquatic communities (but see Guest et al. 1990; DeVries et al. 1991).
A review by DeVries and Stein (1990) suggested that shad Dorosoma spp. may not be ideal forage fishes. Gizzard shad can consistently produce large numbers of offspring from few adults (Miller 1960; Pierce 1977), and their larvae may compete with other fishes for zooplankton (DeVries and Stein 1992). Furthermore, because gizzard shad grow quickly (Bodola 1966), they often reach a size refuge from most predators by the end of their first year (Adams and DeAngelis 1987; Johnson et al. 1988). Impressive larval production coupled with fast growth limits predator consumption to a maximum of $30 \%$ of gizzard shad production, at least in Ohio reservoirs (Carline et al. 1984; Johnson et al. 1988). Most importantly, however, gizzard shad are opportunistic omnivores, feeding on zooplankton as larvae (Barger and Kilambi 1980; DeVries et al. 1991), but capable of switching to phytoplankton or detritus as juveniles and aduits (Kutkuhn 1958; Miller 1960; Bodola 1966; Pierce et al. 1981). Consequently, gizzard shad can drive zooplankton to extinction, yet still survive and grow to adulthood.

Because gizzard shad are quite fecund and spawn before many sport fishes (e.g., bluegill Lepomis macrochirus), their larvae may deplete zooplankton resources to the extent that sport-fish larvae may face unfavorable conditions for growth and survival. Whereas adult and juvenile fishes consume a wide range of prey types, most fishes are zooplanktivorous as larvae (Siefert 1972; Keast 1980; Beard 1982; Rajasilta and Vuorinen 1983; Michaletz et al. 1987), creating the potential for 
exploitative competition if the single food resource, zooplankton, is limiting. Such a severe ontogenetic and competitive bottleneck (sensu Werner and Gilliam 1984) could profoundly affect recruitment of all fishes with zooplanktivorous larvae.

Because gizzard shad larvae are very abundant in several Ohio reservoirs, they may be directly responsible for midsummer zooplankton declines (DeVries and Stein 1992). Such direct trophic interactions can lead to complex effects on the entire community (Carpenter et al. 1987), including increased phytoplankton blooms due to increased planktivory (Carpenter et al. 1985; Scavia et al. 1988), as well as reduced forage for predators due to poor survival among competing zooplanktivores. Several studies (Carpenter et al. 1987; Mills et al. 1987; Scavia et al. 1988; Hall and Ehlinger 1989) have indicated that strong effects originating from one trophic level can cascade through the community for several years. Thus, gizzard shad may influence the entire aquatic community in ways fisheries scientists historically have not thought was possible.

To evaluate the effect that larval gizzard shad might have on the crustacean zooplankton resource, we quantified larval food consumption by determining gut contents and evacuation rates, and we determined crustacean zooplankton production from field samples in two Ohio reservoirs. By calculating the consumptive demand of larval gizzard shad and comparing these values with zooplankton productivity, we could evaluate whether larval gizzard shad predation contributes substantially to midsummer zooplankton declines in small Ohio reservoirs.

\section{Methods}

Study sites. - Knox and Kokosing lakes (Knox County) are small, relatively shallow reservoirs in east-central Ohio. Knox Lake has a surface area of 225 hectares, about $19.2 \mathrm{~km}$ of shoreline, and a maximum depth of $9.6 \mathrm{~m}$; Secchi depths ranged from 47 to $106 \mathrm{~cm}$ during May-June 1988 . With a surface area of 65 hectares, Kokosing Lake has $7.5 \mathrm{~km}$ of shoreline, and a maximum depth of 4.9 $\mathrm{m}$; Secchi depths ranged from 32 to $101 \mathrm{~cm}$ during May-July 1988. Both lakes are in largely agricultural areas; Knox Lake drains about $81 \mathrm{~km}^{2}$ and Kokosing Lake about $87 \mathrm{~km}^{2}$. Neither lake stratified thermally, but Knox Lake became anoxic below $4.5 \mathrm{~m}$ after June 14. Fish communities in both lakes consisted primarily of largemouth bass $\mathrm{Mi}$ cropterus salmoides, gizzard shad, crappies $\mathrm{Po}$ - moxis spp., bluegill, channel catfish Ictalurus punctatus, and brown bullhead Ameiurus nebulosus.

Sampling methods. - We sampled larval fish weekly in both lakes for at least 6 weeks immediately after larval gizzard shad first appeared in 1988. Larvae were collected by towing a $0.75-\mathrm{m}$ diameter, metered ichthyoplankton net $(500-\mu \mathrm{m}$ mesh) along the surface at $1.0-1.5 \mathrm{~m} \cdot \mathrm{s}^{-1}$ for $3-5$ min. Larvae were preserved immediately in $10 \%$ formalin, returned to the laboratory, and identified, counted, and measured (up to 50/species) to the nearest millimeter in total length (TL). For each sample date, we estimated larval density, mean larval size, diet composition, food consumption, and gastric evacuation rate. Density of larvae used to compute larval food consumption was always calculated as the mean of all samples taken between 2200 and 2400 hours because nighttime larval densities were always at least twice daytime estimates. To estimate food consumption, larvae were sampled every $1.5 \mathrm{~h}$ from sunrise to sunset; at sunset, we sampled larvae every 15 $\min$ for at least $3 \mathrm{~h}$ to quantify evacuation rates. Because larval gizzard shad did not feed after dark, their evacuation rate could be quantified by monitoring gut contents beginning immediately after sunset.

We calculated gastric evacuation rates and food consumption of larval and early juvenile gizzard shad (5-30 mm TL) with a model developed by Elliott and Persson (1978) and used for several fishes (Elliott and Persson 1978; Persson 1979, 1982; Cochran and Adelman 1982). This model requires assumptions that (1) food consumption is constant during the interval between samples, and (2) evacuation rate is exponential. Thus, rate of change in gut contents can be expressed by the differential equation

$$
d S / d t=F-R S
$$

$S=$ wcight of stomach contents (g stomach contents $\cdot g$ body weight ${ }^{-1}$ );

$t=$ time (h);

$F=$ rate of food consumption $\left(g \cdot g^{-1} \cdot h^{-1}\right)$;

$\boldsymbol{R}=$ evacuation rate $\left(\mathbf{g} \cdot \mathbf{g}^{-1} \cdot \mathbf{h}^{-1}\right)$.

Using the above equation, we could solve for food amounts in stomachs at time $t$ :

$$
S_{t}=S_{0} e^{-R l}+(F / R)\left(1-e^{-R t}\right) .
$$

However, when no food is consumed over a time interval, the above equation reduces to

$$
S_{l}=S_{0} e^{-R t} \text {. }
$$


Thus, we solved for $R$ with equation (3) after we determined the stomach contents at consecutive sample times as well as the time interval between samples. To determine total food consumption $(C)$ (measured in $\mathrm{mg} \cdot \mathrm{g}^{-1} \cdot \mathrm{d}^{-1}$ ), we rearranged equation (2) to solve for $F$, the hourly rate of food consumption

$$
F=R\left(S_{l}-S_{0} e^{-R t}\right) /\left(1-e^{-R t}\right) .
$$

Then, we solved for total food consumption with the equation

$$
C=F t \text {. }
$$

To estimate the weight of gut contents for larval gizzard shad, we used a technique developed by Post and McQueen (1988), by which the emptygut weight is subtracted from the combined weight of the gut contents and gut. To accomplish this, we first regressed empty-gut weight against body weight. Empty-gut weight was determined by removing and weighing entire guts from fish collected at night after evacuation was complete. Body weight was measured by blotting excess water from an individual fish and then immediately weighing it (nearest $0.1 \mathrm{mg}$ ). To determine food biomass in larval guts, we dissected 10 larvae for each sample time. Because the gut at this developmental stage is a simple tube, we weighed the contents of the entire digestive tract from esophagus to anus. We also quantified diet composition of larval gizzard shad ( $N=5 \mathrm{fish} / \mathrm{sample}$ time). Crustacean zooplankton were identified to genus; rotifers were lumped.

To evaluate prey selection, we compared larval gizzard shad diets with zooplankton samples using Chesson's alpha (Chesson 1978, 1983). The formula for this index is

$$
\alpha=\frac{r_{i} / p_{i}}{\sum\left(r_{i} / p_{i}\right)}
$$

$$
\begin{aligned}
r_{i}= & \text { the proportion of prey item } i \text { in the fish's } \\
& \text { diet; } \\
p_{i}= & \text { the proportion of prey item } i \text { in the en- } \\
& \text { vironment. }
\end{aligned}
$$

For each zooplankton taxon, we compared our calculated $\alpha( \pm 95 \%$ confidence interval, $\mathrm{CI})$ to the expected $\alpha$ if prey were eaten in proportion to their availability. Thus, a prey taxon was selected if $\alpha$ was greater than the reciprocal of the number of prey types in the environment (Chesson 1978, 1983).

Zooplankton were sampled twice weekly in both lakes. One sample was taken simultaneously with larval gizzard shad collections; a second sample was collected 3-5 d later. Each zooplankton sample included two replicate day hauls and two replicate night hauls on dates when larval fish were collected. Crustacean zooplankton and rotifers were sampled with a $0.3-\mathrm{m}$-diameter plankton net (70- $\mu \mathrm{m}$ mesh) towed vertically through the entire water column and preserved in $5 \%$ sucrose formalin (Haney and Hall 1973). We counted all individuals in rare taxa $(<200$ individuals per sample); for abundant taxa, 5\% subsamples were counted until at least 200 individuals had been counted. Up to 50 individuals of each taxon in a sample were measured (nearest $0.01 \mathrm{~mm}$ ) with a digitizing tablet viewed through a drawing tube attached to a microscope. These lengths were converted to biomass with taxon-specific, length-dry weight regressions (Culver et al. 1985).

We evaluated crustacean zooplankton production $(P)$ by calculating the population biomass $(B)$ for each taxon and estimating $P$, following the methods of Bean (1980). We determined temperature-specific $P / B$ ratios by regressing $P / B$ ratio on temperature for taxa of interest, using data from Lake Erie (D. A. Culver, Ohio State University, personal communication). We then multiplied the existing biomass of each taxon on each date by the temperature-dependent $P / B$ ratio for those taxa to determine taxon-specific production. We simply added the production of each taxon to determine total crustacean zooplankton production for each date. With this technique, we assumed that taxon-specific $P / B$ ratios vary slightly across a range of trophic states (Plante and Downing 1989). In addition, crustacean zooplankton production was calculated explicitly (sensu Culver and DeMott 1978) on three dates in each lake to evaluate the accuracy of estimating $P / B$ ratios.

To determine if larval gizzard shad substantially reduced crustacean zooplankton biomass, we used a simple mass-balance equation:

$$
B_{k}=B_{0}+k P-k C \text {; }
$$

$B_{k}=$ crustacean zooplankton biomass at the end of the interval of $k$ days $\left(\mathrm{mg} \cdot \mathrm{m}^{-3}\right.$, wet weight);

$B_{0}=$ crustacean zooplankton biomass at the beginning of each interval $\left(\mathrm{mg} \cdot \mathrm{m}^{-3}\right.$, wet weight);

$k=$ number of days in each interval $(N=3$ or 4 );

$P=$ crustacean zooplankton production at the beginning of the interval ( $\mathrm{mg} \cdot \mathrm{m}^{-3} \cdot \mathrm{d}^{-1}$, wet weight);

$C=$ larval gizzard shad consumption of crus- 


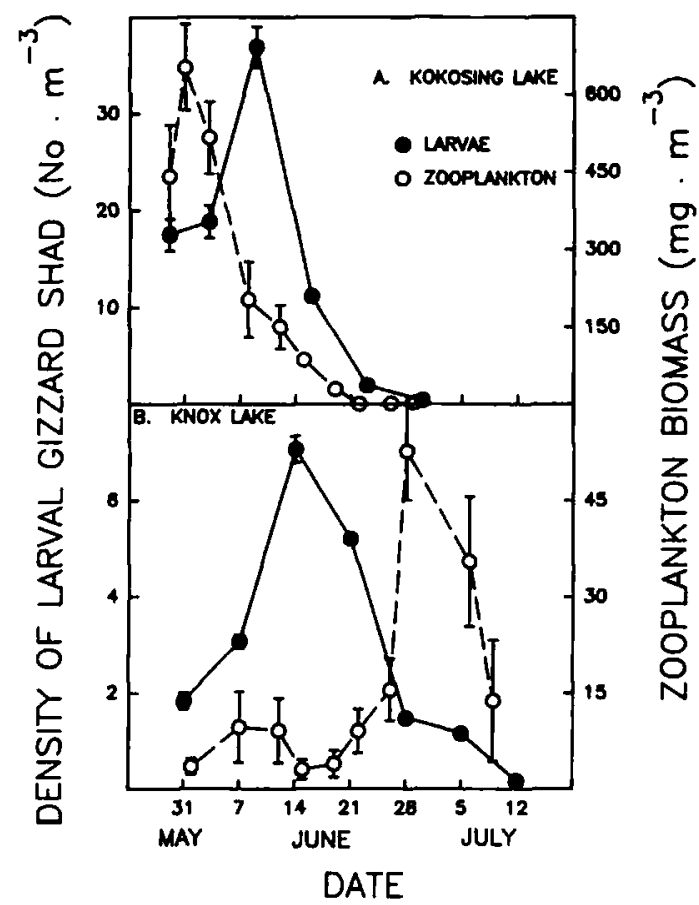

Figure 1.-Density of larval gizzard shad and of crustacean zooplankton biomass (dry weight) in (A) Kokosing Lake and (B) Knox Lake in Ohio, May-July 1988. Note different ordinate scales, reflecting a 5-fold greater density of larval gizzard shad and up to a 10-fold greater crustacean zooplankton biomass in Kokosing Lake. Data are means \pm SEs.

tacean zooplankton, calculated weekly (mg $\cdot \mathrm{m}^{-3} \cdot \mathrm{d}^{-1}$, wet weight).

With this equation we could determine if observed larval gizzard shad densities accounted for the observed decline in crustacean zooplankton, as well as predict the density of larvae or juveniles needed to account for the observed zooplankton decline. When larval gizzard shad consumed prey other than crustacean zooplankton, we estimated crustacean zooplankton consumption by subtracting the weight of zooplankton, determined by length-dry weight regression, from the total weight of food in the gut. Because biomass of zooplankton consumed was expressed as wet weight, and resource estimates of zooplankton biomass were expressed as dry weight, we converted dry weight to wet weight with a $1: 10$ (dry: wet) ratio (Balvay 1987).

\section{Results}

Larval gizzard shad were first collected in Kokosing and Knox lakes in late May; larval densi-

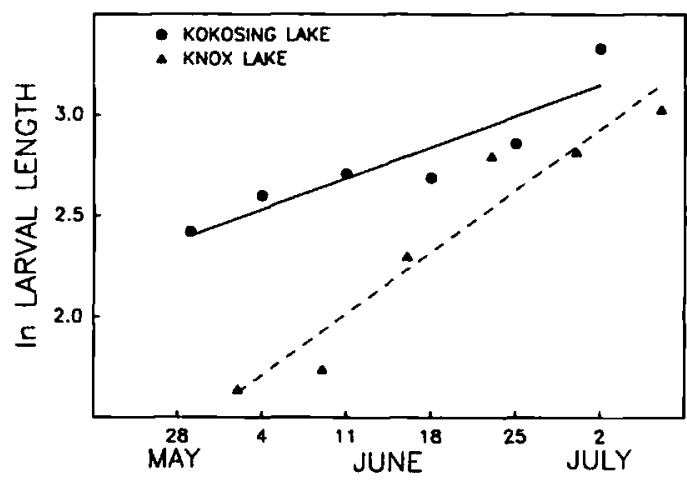

Figure 2.-Growth of larval gizzard shad in Kokosing and Knox lakes, Ohio, May-July 1988. Ordinate is $\log _{e}$ (length).

ties peaked in both lakes in mid-June (Figure 1). Nighttime densities were greater than daytime densities on each sampling date in both lakes (repeated-measures analysis of variance: $F=8.05$; $\mathrm{df}=1,5 ; P=0.04$ in Kokosing Lake and $F=$ 7.54; $\mathrm{df}=1,5 ; P=0.04$ in Knox Lake); thus, we used nighttime density as an estimate of larval abundance. Peak density differed between lakes: $38 \pm 0.62 \mathrm{fish} \cdot \mathrm{m}^{-3}$ (mean $\pm \mathrm{SE}$ ) in Kokosing Lake as compared with $7 \pm 0.28 \mathrm{fish} \cdot \mathrm{m}^{-3}$ in Knox Lake (two sample $t$-test: $P=0.0002$ ). Larval densities declined rapidly after the peak. This decline likely was a combination of mortality and gear avoidance, larvae larger than $20 \mathrm{~mm}$ TL avoiding the net.

Larval growth differed between lakes (analysis of covariance: homogeneity of intercept, $P=0.017$; homogeneity of slope, $P=0.032$; Figure 2 ). Kokosing Lake larvae were larger (11.44 $\pm 0.34 \mathrm{~mm}$, mean $\pm S E)$ than Knox Lake larvae $(5.16 \pm 0.64$ $\mathrm{mm}$ ) when first sampled on May 28 , suggesting earlier spawning by gizzard shad in Kokosing Lake. Kokosing Lake larvae were always at least $1.5 \mathrm{~mm}$, but at most $7 \mathrm{~mm}$, larger than Knox Lake larvae during late May through early July; however, Kokosing Lake larvae grew at only half the rate of Knox Lake larvae.

Crustacean zooplankton composition and abundance also differed markedly between lakes. Whereas Bosmina spp. dominated Kokosing Lake, copepods were dominant in Knox Lake (Figure 3). Crustacean zooplankton abundance increased quickly and peaked at the end of May in Kokosing Lake, declining to near zero by June 21 (Figure IA). Crustacean zooplankton in Knox Lake did not exhibit the typical spring peak in biomass (Figure 1B); instead, a bloom of Diaphanosoma 


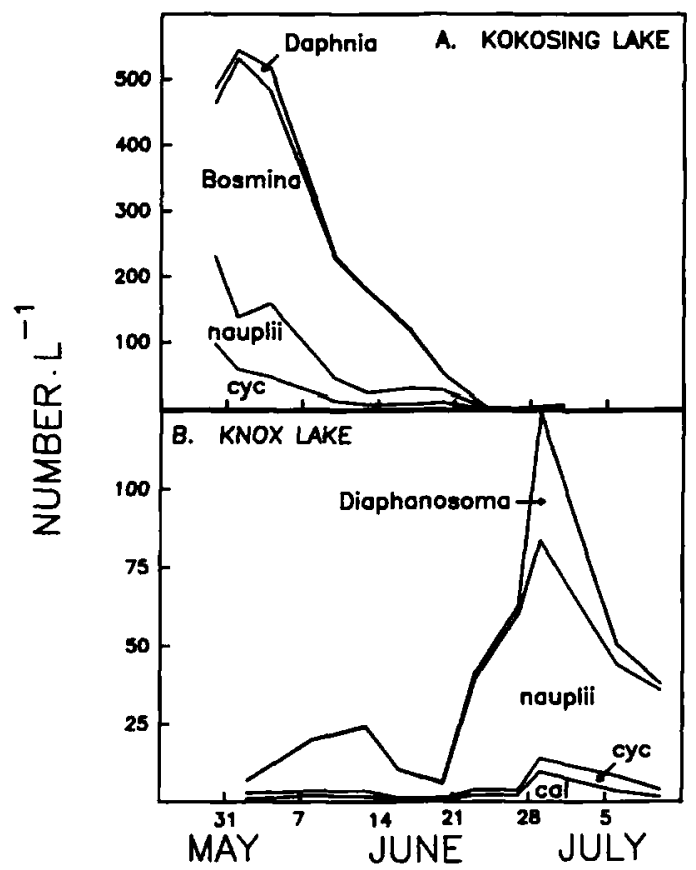

Figure 3.-Crustacean zooplankion abundance and composition in (A) Kokosing Lake and (B) Knox Lake in Ohio, May-July 1988. Abbreviations for taxa: cyc = cyclopoid copepods; $\mathrm{cal}=$ calanoid copepods.

spp. caused zooplankton biomass to peak near the end of June, although copepod nauplii numbers also increased dramatically (Figure 3B).

Macrozooplankton biomass in Kokosing Lake (652 \pm 84 [SE] $\mathrm{mg} \cdot \mathrm{m}^{-3}$ ) exceeded that in Knox Lake $\left(3.55 \pm 0.94 \mathrm{mg} \cdot \mathrm{m}^{-3}\right)$ on May 31 , before larval gizzard shad were near peak abundance (two sample $t$-test, $P=0.041$ ). Crustacean zooplankton production, estimated by $P / B$ ratios, peaked in Kokosing Lake at the end of May. Production fell steadily thereafter, reaching a minimum on June 23. Crustacean zooplankton production in Knox Lake remained low until June 26 . Production increased after June 28 due to a Diaphanosoma bloom. These production estimates were compared with explicitly calculated production values (as per the methods of Culver and DeMott 1978) on May 31, June 3, and June 19 (Table 1). In all cases, calculated production values did not differ from values estimated by $P / B$ ratios (paired $t$-test, $P>0.30$ ).

Because food consumption and diet composition changed as larvae grew, at least in Kokosing Lake, we analyzed diet composition and food consumption for small (5-17 mm TL) and large (18$24 \mathrm{~mm}$ TL) larvae. Diet composition and esti-
TABLE 1.-Comparison of calculated versus estimated crustacean zooplankton production $(P)$ in Kokosing and Knox lakes, Ohio, May 31, June 2, and June 19, 1988. $B$ is biomass.

\begin{tabular}{ccc}
\hline Date & $\begin{array}{c}P \text { estimated } \\
\text { from } \\
P / B \text { ratios } \\
\left(\mathbf{m g}^{-3} \cdot \mathbf{m}^{-3} \cdot \mathbf{d}^{-1}\right)\end{array}$ & $\begin{array}{c}P \text { calculated } \\
\text { from zoo- } \\
\text { plankton data } \\
\left(\mathbf{m g}^{-1} \cdot \mathbf{m}^{-3} \cdot \mathbf{d}^{-1}\right)\end{array}$ \\
\hline Kokosing Lake \\
May 31 & 131.71 & 188.43 \\
Jun 2 & 81.50 & 86.02 \\
Jun 19 & 2.92 & 2.87 \\
& Knox Lake & \\
May 31 & 0.29 & 0.31 \\
Jun 2 & 0.48 & 0.45 \\
Jun 19 & 0.34 & 0.28 \\
\hline
\end{tabular}

mated food consumption were quantified for early juveniles (25-30 mm TL) in Kokosing Lake only. In Kokosing Lake, small larval gizzard shad primarily consumed cyclopoid copepodites and nauplii on or before June 9 (Table 2), when larvae reached their peak abundance. After June 9, larvae consumed smaller proportions of cyclopoids $(t$-test, $P<0.0001)$, Daphnia $(P=0.0031)$, and nauplii $(P<0.0001)$ but a larger proportion of rotifers $(P<0.0001)$. Large larvae primarily consumed cyclopoid copepodites, Bosmina, and Daphnia on or before June 9 (Table 2); however, these large larvae ate smaller proportions of cyclopoids $(P=0.015)$, Bosmina $(P=0.028)$, and Daphnia $(P=0.036)$, but more rotifers $(P<$ 0.0001 ) after June 9 . Before peak larval densities on June 9, large larvae consumed greater proportions of Bosmina $(P=0.012)$ and Daphnia $(P=$ $0.04)$, but a smaller proportion of nauplii $(P<$ 0.0001 ) than smaller larvae. After the larval peak, large larvae ate proportionately more Bosmina than small larvae $(P=0.05)$. By July 1 , all larvae fed entirely on rotifers and detritus in the absence of crustacean zooplankton.

Prey selection by small larval gizzard shad, determined via Chesson's alpha (Chesson 1978, 1983), reinforces this dietary pattern. Small larvae selected (1) copepod nauplii and cyclopoid copepodites before crustacean zooplankton populations crashed (May 28-June 2; Table 3), (2) cyclopoid copepodites during the crash (June 9-16), and (3) no crustacean zooplankton after the crash (June 23). Large larvae preferred (1) cyclopoid copepodites before the crash, (2) Bosmina and Daphnia during the crash, and (3) no crustacean zooplankton after the crash. Rotifer electivities were not calculated because we did not accurately estimate rotifer density. 
TABle 2.-Diet composition of larval gizzard shad ( $N=25$ small and 15 large larvae per date) described as the proportion by number (mean \pm SE) of each zooplankton taxon consumed on each date in Kokosing Lake, Ohio, May-July 1988. Calanoid copepods, although present, contributed proportions of less than 0.01 to diets of larval gizzard shad. Proportions of Daphnia spp. were important only on June 9, when they were $0.31 \pm 0.12$ in the diets of large larvae. TL is total length.

\begin{tabular}{|c|c|c|c|c|c|}
\hline \multirow[b]{2}{*}{ Date } & \multirow[b]{2}{*}{$\begin{array}{l}\text { Total prey } \\
\text { counted }\end{array}$} & \multicolumn{4}{|c|}{ Dietary proportions of: } \\
\hline & & $\begin{array}{l}\text { Cyclopoid } \\
\text { copepodites }\end{array}$ & Bosmina spp. & $\begin{array}{l}\text { Copepod } \\
\text { nauplii }\end{array}$ & Rotifers \\
\hline \multicolumn{6}{|c|}{ Small larvae (5-17 mm TL) } \\
\hline $\begin{array}{l}\text { May } 28 \\
\text { Jun } 2 \\
\text { Jun } 9 \\
\text { Jun } 16 \\
\text { Jun } 23\end{array}$ & $\begin{array}{r}842 \\
1,145 \\
1.216 \\
1.347 \\
2.630\end{array}$ & $\begin{array}{c}0.60 \pm 0.03 \\
0.62 \pm 0.06 \\
0.51 \pm 0.05 \\
0.08 \pm 0.04 \\
<0.01\end{array}$ & $\begin{array}{l}0.01 \pm 0.01 \\
0.06 \pm 0.02 \\
0.03 \pm 0.01 \\
0.03 \pm 0.02 \\
0.02 \pm 0.01\end{array}$ & $\begin{array}{c}0.34 \pm 0.03 \\
0.27 \pm 0.06 \\
0.25 \pm 0.04 \\
0.04 \pm 0.02 \\
<0.01\end{array}$ & $\begin{array}{l}0.04 \pm 0.01 \\
0.03 \pm 0.01 \\
0.20 \pm 0.06 \\
0.85 \pm 0.06 \\
0.98 \pm 0.01\end{array}$ \\
\hline \multicolumn{6}{|c|}{ Large larvae (18-24 $\mathrm{mm}$ TL) } \\
\hline $\begin{array}{l}\text { Jun } 2 \\
\text { Jun } 9 \\
\text { Jun } 16 \\
\text { Jun } 23\end{array}$ & $\begin{array}{r}2.690 \\
3.429 \\
10.378 \\
6,819\end{array}$ & $\begin{array}{c}0.69 \pm 0.14 \\
0.22 \pm 0.09 \\
0.05 \pm 0.02 \\
0\end{array}$ & $\begin{array}{c}0.25 \pm 0.12 \\
0.39 \pm 0.13 \\
0.16 \pm 0.05 \\
<0.01\end{array}$ & $\begin{array}{c}<0.01 \\
0.01 \pm 0.01 \\
0.04 \pm 0.02 \\
0\end{array}$ & $\begin{array}{l}0.06 \pm 0.03 \\
0.06 \pm 0.04 \\
0.75 \pm 0.08 \\
0.99 \pm 0.01\end{array}$ \\
\hline
\end{tabular}

Diets did not differ between small and large larvae in Knox Lake ( $t$-test, $P>0.43$ ). Larval diets in Knox Lake included up to $32 \%$ crustacean zooplankton, and the remainder was composed of rotifers (Table 4), most likely as a result of low crustacean zooplankton biomass (Figure 1).

Larval gizzard shad in Knox Lake ate crustacean zooplankton in proportion to their availability during May through July (Table 4). Larvae never selected Diaphanosoma, although it was abundant during the zooplankton peak in late June (Figure 3).

TABle 3. - Prey selection by larval gizzard shad $(N=$ 25 small and 15 large larvae per date) described by Chesson's alpha (mean \pm SE) for each zooplankton taxon present in larval diets in Kokosing Lake, Ohio, MayJuly 1988. Values of alpha greater than 0.17 (the reciprocal of the number of taxa present in the lake) indicate positive selection; smaller values indicate nonpreferred taxa. Calanoid copepods were never selected by larval gizzard shad; Daphnia spp. were preferred only on June 9 , when large larvae strongly selected them (alpha $=0.69$ \pm 0.09 ). TL is total length.

\begin{tabular}{lllc}
\hline Date & $\begin{array}{c}\text { Cyciopoid } \\
\text { copepodites }\end{array}$ & Bosmina spp. & $\begin{array}{c}\text { Copepod } \\
\text { nauplii }\end{array}$ \\
\hline \multicolumn{4}{c}{ Small larvae (5-17 mm TL) } \\
May 28 & $0.69 \pm 0.03$ & $0.01 \pm 0.004$ & $0.30 \pm 0.03$ \\
Jun 2 & $0.77 \pm 0.05$ & $0.01 \pm 0.01$ & $0.18 \pm 0.05$ \\
Jun 9 & $0.81 \pm 0.03$ & $0.01 \pm 0.003$ & $0.16 \pm 0.03$ \\
Jun 16 & $0.20 \pm 0.07$ & $0.07 \pm 0.03$ & $0.05 \pm 0.03$ \\
Jun 23 & $0.05 \pm 0.05$ & $0.23 \pm 0.09$ & $0.03 \pm 0.03$ \\
\multicolumn{5}{c}{ Large larvae (18-24 mm TL) } \\
Jun 2 & $0.93 \pm 0.04$ & $0.06 \pm 0.04$ & $<0.01$ \\
Jun 9 & $0.23 \pm 0.06$ & $0.08 \pm 0.05$ & $<0.01$ \\
Jun 16 & $0.28 \pm 0.08$ & $0.30 \pm 0.04$ & $0.09 \pm 0.04$ \\
Jun 23 & 0 & $<0.01$ & 0 \\
\hline
\end{tabular}

Food consumption was calculated by coupling the amount of food in larval guts through time with larval evacuation rates. Based on gut analyses, larvae fed continuously at a constant rate during daylight (regression analysis: slope no different from zero, $F$-test; $1,4 \mathrm{df} ; P>0.24$ in all cases), but never fed after sunset (Figures 4,5 ). Because gut evacuation is strongly temperature dependent, we first calculated six larval evacuation rates across the range of $T=20-28^{\circ} \mathrm{C}$. We then regressed evacuation rate $\left(\mathrm{mg} \cdot \mathrm{g}^{-1} \cdot \mathrm{h}^{-1}\right)$ against temperature $(R$ $=-21,024+1,019 T ; r^{2}=0.98 ; F=209.01 ; \mathrm{df}$ $=1,4 ; P<0.001)$ to determine evacuation rates for June-July 1988 .

Mean daily food consumption of individual larval gizzard shad was similar in Kokosing and Knox lakes for a given temperature. Generally, individual consumption was lower in Kokosing Lake due to cooler water temperatures. Food consumption by the entire larval population increased through June 9 and declined thereafter in Kokosing Lake (Table 5). In Knox Lake, the larval gizzard shad population consumed an order of magnitude more food in late June than in late May because of increased larval density and size. Although individual food consumption was similar between lakes, the population of larval gizzard shad consumed more food in Kokosing Lake than in Knox Lake simply because they were more abundant.

In Kokosing Lake, larval gizzard shad consumed more than $100 \%$ of the crustacean zooplankton production only after zooplankton had crashed. Larval gizzard shad in Knox Lake consumed at least $80 \%$ of daily crustacean zooplankton production except on June 7 , when larvae con- 
TABLE 4. - Diet composition and prey selection (mean \pm SE) of larval gizzard shad ( $N=25$ fish/date) in $\mathrm{Knox}$ Lake, Ohio. May-July 1988. Diet composition is presented as the proportion by number of each zooplankton taxon in larval guts on each date, whereas prey selection is described by Chesson's alpha. To evaluate electivity, values greater than 0.17 (the reciprocal of the number of taxa present in the lake) indicate positive selection; smaller values indicate nonpreferred taxa. Calanoid copepods, Bosmina spp., and Diaphanosoma spp., although present, never accounted for dietary proportions greater than 0.01 and were never preferred by larval gizzard shad. Electivities for rotifers were not calculated because they were not efficiently sampled.

\begin{tabular}{|c|c|c|c|c|}
\hline \multirow[b]{2}{*}{ Date } & \multirow[b]{2}{*}{$\begin{array}{l}\text { Total prey } \\
\text { counted }\end{array}$} & \multicolumn{3}{|c|}{ Proportion or electivity of: } \\
\hline & & $\begin{array}{l}\text { Cyclopoid } \\
\text { copepodites }\end{array}$ & $\begin{array}{l}\text { Copepod } \\
\text { nauplii }\end{array}$ & Rotifers \\
\hline \multicolumn{5}{|c|}{ Diet composition } \\
\hline $\begin{array}{l}\text { May 31 } \\
\text { Jun } 7 \\
\text { Jun } 14 \\
\text { Jun 21 } \\
\text { Jul } 5\end{array}$ & $\begin{array}{r}70 \\
147 \\
212 \\
2.374 \\
14.189\end{array}$ & $\begin{array}{l}0.11 \pm 0.06 \\
0.04 \pm 0.02 \\
0.04 \pm 0.03 \\
0.04 \pm 0.02 \\
0.02 \pm 0.004\end{array}$ & $\begin{array}{c}0.21 \pm 0.08 \\
0.12 \pm 0.05 \\
0 \\
<0.01 \\
0.01 \pm 0.004\end{array}$ & $\begin{array}{l}0.68 \pm 0.10 \\
0.84 \pm 0.05 \\
0.96 \pm 0.03 \\
0.95 \pm 0.06 \\
0.96 \pm 0.01\end{array}$ \\
\hline \multicolumn{5}{|c|}{ Prey selection } \\
\hline $\begin{array}{l}\text { May } 31 \\
\text { Jun } 7 \\
\text { Jun } 14 \\
\text { Jun 21 } \\
\text { Jul } 5\end{array}$ & $\begin{array}{r}70 \\
147 \\
212 \\
2.374 \\
14.189\end{array}$ & $\begin{array}{l}0.18 \pm 0.09 \\
0.24 \pm 0.13 \\
0.22 \pm 0.14 \\
0.21 \pm 0.12 \\
0.23 \pm 0.03\end{array}$ & $\begin{array}{c}0.26 \pm 0.10 \\
0.25 \pm 0.12 \\
0 \\
<0.01 \\
0.02 \pm 0.01\end{array}$ & \\
\hline
\end{tabular}

sumed $55 \%$ of crustacean zooplankton production, and on July 5 , when larval densities were extremely low. Larvae consumed more than $450 \%$ of crustacean zooplankton production on June 14 , when larval densities peaked.

Gizzard shad larvae do not exert a strong influence on crustacean zooplankton in Kokosing Lake; however, larvae may be an important source of mortality in Knox Lake. To fully appreciate their influence, we compared larval food consumption with the sum of crustacean zooplankton biomass and production (Table 6). Existing densities of larval gizzard shad could not account for observed crustacean zooplankton decline in Kokosing Lake; only unreasonably high larval densities (60-212 larvae $\cdot \mathrm{m}^{-3}$ ) could be expected to consume enough zooplankton to cause the observed decline.

However, juvenile gizzard shad occasionally were captured in ichthyoplankton tows, first appearing on June 2. Enough juveniles were collected to determine diet composition and amount of food in the digestive system during daylight hours. Juvenile diets were similar to those of large larvae during June 2-16 (two-sample t-test, $P>0.14$ ). Assuming that evacuation rates for juvenile gizzard shad $25-30 \mathrm{~mm}$ TL declined by $15 \%$ as compared with larval evacuation rates (Mills and Forney 1981), we estimated individual juvenile food consumption (Table 5) and determined the number, of juvenile gizzard shad required to cause the observed zooplankton decline. Fitting the observed zooplankton decline to estimated con- sumption by larvae plus juveniles, we calculated that $1.3-17.8$ juveniles $\cdot \mathrm{m}^{-3}$ would account for the crustacean zooplankton declines in Kokosing Lake (Table 6). These are not unreasonable juvenile densities for Kokosing Lake because Johnson et al. (1988) quantified mean densities at 12.8 juveniles $\cdot \mathrm{m}^{-3}$ over the growing season and a maximum density of 20 juveniles $\mathrm{m}^{-3}$. Although larval consumption alone was not responsible for the crustacean zooplankton decline in Kokosing Lake, additional consumption by early juveniles, combined with larval consumption, likely drove zooplankton to low levels.

In Knox Lake, gizzard shad larvae had variable effects on zooplankton biomass (Table 6). During the week of May 31, larval food consumption could have accounted for zooplankton changes, but it did not prevent zooplankton biomass from increasing during the week of June 7. From June 14 to 22 , existing larval densities were more than sufficient to account for changes in zooplankton biomass. Zooplankton biomass increased from June 22 to 28 despite larval gizzard shad predation. After June 28, unreasonably high larval and juvenile densities were required to account for the observed crustacean zooplankton decline.

To summarize, high densities of larvae could not account for the decline in zooplankton when crustacean zooplankton production and biomass were great in Kokosing Lake. Only consumption by juvenile gizzard shad could account for the observed zooplankton decline. However, zooplank- 


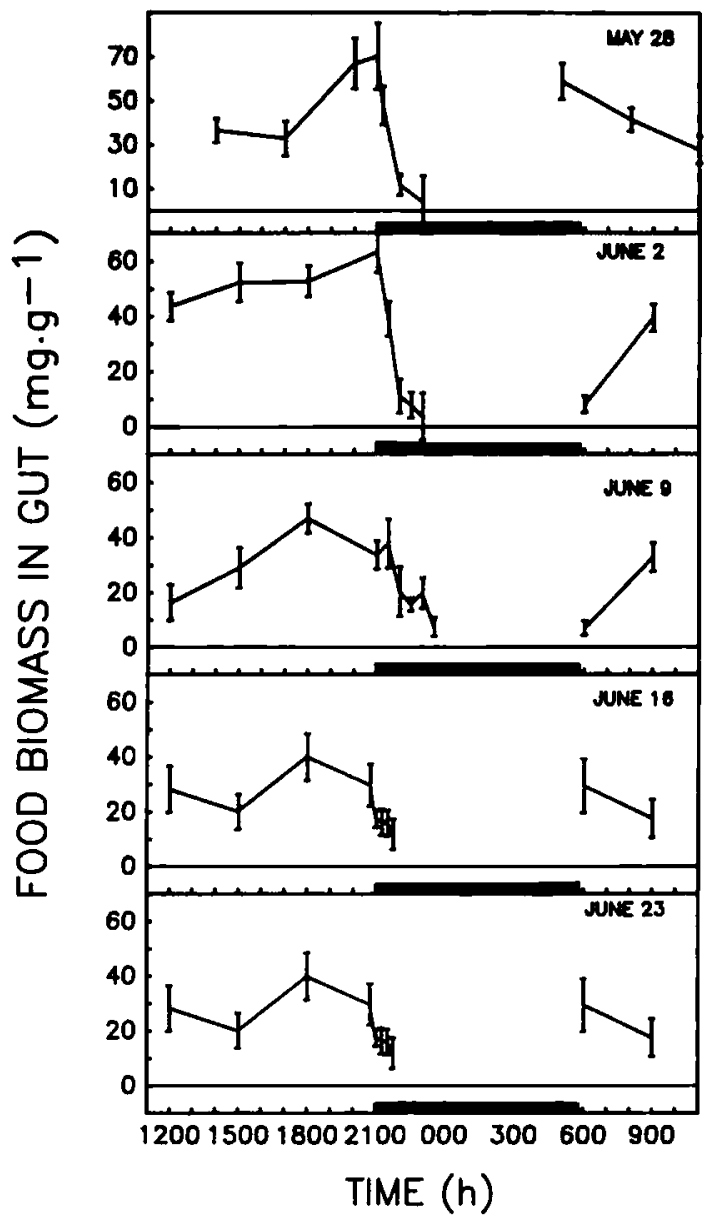

Figure 4. - Diel patterns of gut fullness (means \pm SEs) for gizzard shad larvae in Kokosing Lake, Ohio, May-June 1988. Bars along the abscissa represent dark periods.

ton consumption when larval densities were low was often sufficient to account for the zooplankton dynamics in Knox Lake, where production and biomass were low during May-June 1988.

\section{Discussion}

\section{Larval Food Consumption and Diets}

To sustain their metabolic and growth requirements, larval gizzard shad feed continuously at constant ration levels throughout daylight hours during late May through early July. With continuous and constant feeding, larval gizzard shad were ideal animals with which to quantify food consumption via the Elliott-Persson model (Elliott and Persson 1978).

Gizzard shad larvae do not feed at night; thus,

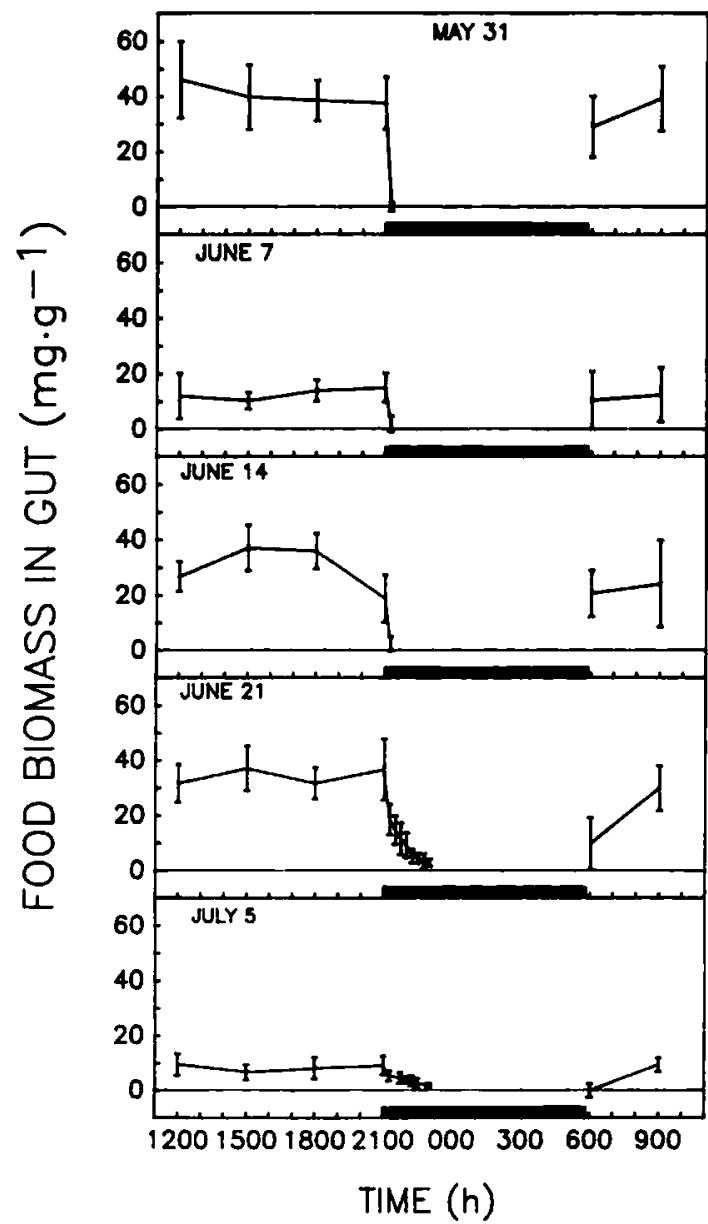

Figure 5.-Diel patterns of gut fullness (means \pm SEs) for gizzard shad larvae in Knox Lake, Ohio, MayJuly 1988 . Bars along the abscissa represent dark periods.

larval gizzard shad are likely visual, particulate feeders, unlike juveniles and adults (Drenner et al. 1982a, 1982b). By measuring the decline in gut contents through time after dark, we could determine evacuation rates in the field. Rarely can evacuation be directly determined from field collections; however, this was a distinct advantage because larval gizzard shad are difficult to collect and manipulate experimentally in the laboratory.

Larval gizzard shad ate crustacean zooplankton when it was abundant during late May-early July. When crustacean zooplankton became scarce, larvae fed on rotifers. Small larvae selected copepod nauplii and copepodites when crustacean zooplankton were abundant. Although large larvae preferred copepodites, they ate few nauplii and consumed more cladocerans than small larvae. 
TABLE 5. - Calculated food consumption by individual small gizzard shad larvae (5-17 mm total length; $N=$ $60 \mathrm{fish} /$ date) and large larvae (18-24 mm; $N=30 \mathrm{fish} /$ date), estimated food consumption by individual juvenile gizzard shad (25-30 mm), and estimated total consumption by the population of larval gizzard shad in Kokosing and Knox lakes, Ohio, May-July 1988.

\begin{tabular}{|c|c|c|c|c|}
\hline \multirow[b]{2}{*}{ Date } & \multicolumn{3}{|c|}{$\begin{array}{l}\text { Individual consumption } \\
\left(\mathrm{mg} \cdot \mathrm{g}^{-1} \cdot \mathrm{d}^{-1}\right) \text { by: }\end{array}$} & \multirow{2}{*}{$\begin{array}{c}\text { Population } \\
\text { consumption } \\
\left(\mathrm{mg} \cdot \mathrm{m}^{-3} \cdot \mathrm{d}^{-1}\right) \\
\text { all larvae }\end{array}$} \\
\hline & $\begin{array}{l}\text { Small } \\
\text { larvae }\end{array}$ & $\begin{array}{l}\text { Large } \\
\text { larvae }\end{array}$ & $\begin{array}{l}\text { Juve- } \\
\text { niles }\end{array}$ & \\
\hline \multicolumn{5}{|c|}{ Koloosing Lakea } \\
\hline May 29 & 2.383 & NP & NP & 146 \\
\hline Jun 2 & 736 & 994 & 728 & 158 \\
\hline Jun 9 & 358 & 540 & 672 & 263 \\
\hline Jun 16 & 693 & 831 & 1.520 & 115 \\
\hline Jun 23 & 1.510 & 1.743 & $N^{b}$ & 37 \\
\hline \multicolumn{5}{|c|}{ Knox Lake } \\
\hline May 31 & 2.995 & NP & NP & 13 \\
\hline Jun 7 & 656 & $\mathbf{N P}$ & $\mathbf{N P}$ & 11 \\
\hline Jun 14 & 2.777 & NP & NP & 133 \\
\hline Jun 21 & 3,351 & 3,753 & $\mathbf{N P}$ & 189 \\
\hline Jul 5 & 851 & 978 & $\mathbf{N P}$ & 32 \\
\hline
\end{tabular}

NP = larval and juvenile fish were not present or not collected b $\mathrm{NC}=$ juveniles were not consuming macrozooplankton.

Diaphanosoma composed the bulk of zooplankton in Knox Lake after June 28, yet larvae did not select them. Nevertheless, fish larvae do prefer Diaphanosoma (Van Den Avyle and Wilson 1980; Mallin et al. 1987; DeVries et al. 1991), which is not surprising because Diaphanosoma is larger than most zooplankters in these reservoirs, has no defensive spines, and has poorer escape abilities than copepods (Drenner et al. 1978; Drenner and McComas 1980). Diaphanosoma likely was not selected because deep Knox Lake (maximum depth, $10 \mathrm{~m}$ ) provided a spatial refuge for this vertically migrating zooplankter (Carter et al. 1980; Nero and Sprules 1986).

Based on electivity measures, larvae selected primarily copepods; however, electivity did not always reflect those prey most common in the diet. Large larvae in Kokosing Lake selected Bosmina on only one date; yet more than $25 \%$ of their diet was Bosmina on dates when the cladoceran was not preferred. Caution must be used when electivities are interpreted; if preferred prey are rare, they may only contribute slightly to the diet. However, prey that are simply consumed in proportion to their abundance may be an extremely important energy source if they form a substantial proportion of the prey community. In food consumption studies, actual diet composition is more relevant than diet preference simply because con-
Table 6.-Comparison of observed crustacean zooplankton biomass (see Figure 1) and production with the predicted number of larval and early juvenile gizzard shad required to account for the observed changes in crustacean zooplankton abundance in Kokosing and Knox lakes, Ohio, May-July 1988.

\begin{tabular}{|c|c|c|c|c|}
\hline Date & $\begin{array}{l}\text { Zooplankton } \\
\text { production } \\
\text { (mg-m } m^{-3} \text {. } \\
d^{-1} \text {, wet) }\end{array}$ & $\begin{array}{c}\text { Existing } \\
\text { larval } \\
\text { density } \\
\text { (number-m }{ }^{3} \text { ) }\end{array}$ & $\begin{array}{c}\text { Larvae } \\
\text { re- } \\
\text { quireda } \\
\text { (num- } \\
\text { ber. } \\
m^{3} \text { ) }\end{array}$ & $\begin{array}{c}\text { Juve- } \\
\text { niles } \\
\text { re- } \\
\text { quired } \\
\text { (number- } \\
\mathbf{m}^{-3} \text { ) }\end{array}$ \\
\hline \multicolumn{5}{|c|}{ Kokosing Lake } \\
\hline May 28-31 & $815 \pm 92$ & $17.5 \pm 1.7$ & BI & NP \\
\hline \multicolumn{5}{|l|}{ May 31- } \\
\hline Jun 2 & $1,317 \pm 97$ & $17.5 \pm 1.7$ & 211.8 & 17.8 \\
\hline Jun 2-5 & $806 \pm 81$ & $20 \pm 1.7$ & 180.5 & 13.9 \\
\hline Jun 5-9 & $803 \pm 83$ & $20 \pm 1.7$ & 155.8 & 11.7 \\
\hline Jun $9-12$ & $460 \pm 126$ & $38 \pm 2.1$ & 91.8 & 3.8 \\
\hline Jun 12-16 & $253 \pm 61$ & $38 \pm 2.1$ & 59.8 & 1.5 \\
\hline Jun $16-19$ & $130 \pm 15$ & $11 \pm 0.6$ & 122.0 & 5.2 \\
\hline Jun $19-23$ & $29 \pm 3.5$ & $11 \pm 0.6$ & 37.9 & 1.3 \\
\hline \multicolumn{5}{|c|}{ Knox Lake } \\
\hline \multicolumn{5}{|l|}{ May 31- } \\
\hline Jun 2 & $3 \pm 0.8$ & $2 \pm 0.2$ & 2 & NP \\
\hline Jun $2-7$ & $4 \pm 1.5$ & $2 \pm 0.2$ & 2 & NP \\
\hline Jun $7-12$ & $4 \pm 1.8$ & $3 \pm 0.1$ & 5.6 & NP \\
\hline Jun 12-15 & $5 \pm 2.1$ & $3 \pm 0.1$ & 29.7 & NP \\
\hline Jun 15-19 & $2 \pm 0.5$ & $7 \pm 0.3$ & 1.0 & NP \\
\hline Jun 19-22 & $3 \pm 0.6$ & $7 \pm 0.3$ & 7.0 & NP \\
\hline Jun 22-26 & $9 \pm 2.9$ & $5 \pm 0.1$ & BI & NP \\
\hline Jun $26-28$ & $10 \pm 2.2$ & $5 \pm 0.1$ & BI & NP \\
\hline \multicolumn{5}{|l|}{ Jun 28- } \\
\hline Jul 5 & $41 \pm 6.7$ & $2 \pm 0.1$ & 16.3 & 27.4 \\
\hline Jul 5-9 & $29 \pm 5.9$ & $1 \pm 0.1$ & 85.2 & 47.6 \\
\hline
\end{tabular}

BI $\approx$ zooplankton biomass increased during the interval despite predation by larval gizzard shad.

b NP $=$ juveniles were not present in the lake.

sumption estimates are based on diets, not on food choice.

All zooplankton taxa, with the exception of Diaphanosoma in Knox Lake, were vulnerable to gizzard shad during at least part of that species' larval development. Because zooplankton were vulnerable, larval gizzard shad have the potential to strongly influence plankton community dynamics if their consumption exceeds crustacean zooplankton production. Based on comparisons between larval food consumption and the sum of crustacean zooplankton biomass plus production during late May through early July, we conclude that gizzard shad larvae at low densities likely consumed enough crustacean zooplankton in Knox Lake, where zooplankton biomass and production were low, to prevent crustacean zooplankton from increasing until after June 21. Conversely, in Kokosing Lake, where zooplankton biomass and production were high, even high densities of larval 
gizzard shad had only a minor effect on zooplankton assemblages. Instead, although the source of the initial decline in crustacean zooplankton is unclear, once zooplankton began to decrease, zooplankton consumption by early juvenile gizzard shad may have accounted for the observed decline in zooplankton.

Low densities of larval gizzard shad in Knox Lake had a greater effect on zooplankton than did high densities in Kokosing Lake for two reasons. First, zooplankton production and biomass were three orders of magnitude lower in Knox Lake on May 31 , whereas peak larval densities were $20 \%$ of those in Kokosing Lake. Thus, Knox Lake larvae initially exerted a larger predatory pressure on their zooplankton resource than did Kokosing Lake larvae.

Second, zooplankton composition differed between lakes; Kokosing Lake was rich in cladocerans whereas Knox Lake was dominated by copepods. Given differences in turnover rate between the two taxa and that small larvae prefer copepods over cladocerans, this difference is important. Generation times are 3-5 d for cladocerans (Gulyas 1980) but 2-3 weeks for copepods (Gulyas 1980; Webb and Parsons 1988) across our observed temperature range. Thus, the copepoddominated zooplankton assemblage in Knox Lake had more difficulty maintaining itself in the face of mortality (e.g., predation) than the cladocerandominated assemblage of Kokosing Lake. In addition, the entire zooplankton assemblage in Knox Lake was not only available to, but was also preferred by, larval gizzard shad. Thus, Knox Lake larvae could maintain predatory pressure sufficient to prevent zooplankton accumulation until Diaphanosoma appeared.

Although gizzard shad larvae were quite abundant in Kokosing Lake, their effect on zooplankton was insignificant because they primarily ate copepodites and nauplii. Copepods were responsible for less than $6 \%$ of crustacean zooplankton production; thus, although larvae most likely reduced copepod abundance (from 20\% of zooplankton on May 28 to $6 \%$ on June 9), overall production and biomass did not decline until large larvae and juveniles began consuming cladocerans on June 2.

Gizzard shad larvae may select nauplii and copepodites in Kokosing Lake because of gape limitations, even though the crustacean zooplankton assemblage was dominated by cladocerans (53$80 \%$ of the zooplankton during May 28-June 9). Gape size influences diet and perhaps success of larval fishes (Hunter and Kimbrell 1980; Dabrowski et al. 1984; Michaletz et al. 1987). For example, larval pollan Coregonus pollan feed on nauplii and copepodids until they reach $20 \mathrm{~mm}$, when they switch to larger zooplankters, including adult copepods and Daphnia (Dabrowski et al. 1984). Maximum prey size consumed by pollan smaller than $13 \mathrm{~mm}$ did not differ from mean prey size. Conversely, larval pollan larger than $13 \mathrm{~mm}$ ate prey smaller than their gape size would dictate, suggesting that pollan were no longer gape-limited. Increasing gape size permitted larval pollan to shif from small to large prey.

Similarly, when feeding on crustacean zooplankton, larval gizzard shad 5-17 mm TL from Kokosing Lake predominately consumed copepods (nauplii and copepodites) during May 28June 9, whereas larvae 18-24 mm TL primarily consumed cladocerans during June 9-16. In an assessment of the importance of zooplankton size to survival of larval fishes, M. Bremigan (Ohio State University, personal communication) determined gape size of 17-mm (TL) larval gizzard shad to be $0.45 \mathrm{~mm}$ in diameter. If larval gizzard shad eat prey $26 \%$ of their gape (as $12-\mathrm{mm}$ larval pollan do: Dabrowski et al. 1984), a 17-mm larva could consume zooplankters only $0.12 \mathrm{~mm}$ in the limiting dimension. Presumably, smaller larval gizzard shad would have an even more stringent prey size restriction. In Kokosing Lake on June 9, prey had the following mean widths: copepodites, 0.15 $\mathrm{mm}$; nauplii, $0.10 \mathrm{~mm}$; Bosmina, $0.22 \mathrm{~mm}$; Daphnia, $0.33 \mathrm{~mm}$. Thus, only copepodites and nauplii have size distributions that put large proportions of their populations at risk from larval gizzard shad predation. Hence, because of interactions between gape size and the zooplankton assemblage, gizzard shad larvae may strongly influence plankton dynamics in copepod-dominated Knox Lake, but not in cladoceran-dominated Kokosing Lake.

Larval gizzard shad had less effect than juveniles in Kokosing Lake simply because their consumptive demand was so much smaller, owing to allometric growth patterns (Peters 1983). As larvae, gizzard shad grow primarily in length. At metamorphosis (about $25 \mathrm{~mm} \mathrm{TL}$ ), however, individuals add considerably more weight per unit of length added. For each $20 \%$ length increase as larvae, weight increases by a factor of 1.8 ; as larvae metamorphose, weight increases by a factor of 5 for a similar length increase (J. M. Dettmers, unpublished data). Because food consumption is directly related to weight, consumptive demand increases dramatically as larvae become early ju- 
veniles. Thus, consumption by juveniles may have overwhelmed the reproductive capacity of the crustacean zooplankton community, driving zooplankton biomass to low levels.

This interpretation agrees with that presented by DeVries and Stein (1992), whose experiment contained fishless exclosures and gizzard shad enclosures. Stocked into bags at $18 \mathrm{~mm}$ and growing to $40 \mathrm{~mm}$ during the 4-week experiment, gizzard shad drove zooplankton to extinction. Conversely, in fishless exclosures, zooplankton maintained high densities. Our estimates of zooplankton consumption by gizzard shad in the same lake and year, combined with this experiment, strongly suggest that larval, and especially juvenile, gizzard shad are a major source of mortality contributing to the observed decline of crustacean zooplankton.

Although consumption by larval and juvenile gizzard shad may explain crustacean zooplankton dynamics during May-July in both study lakes, other factors likely play important roles in regulating zooplankton dynamics. In Kokosing Lake, the initial phase of the zooplankton decline (May 31-June 5) cannot be fully attributed to gizzard shad. Larval densities were probably too low to produce the densities of juveniles needed to account for the decline at the end of May. A possible explanation for the crustacean zooplankton decline is consumption by other planktivorous fishes (e.g., adult gizzard shad, bluegills, and crappies). This scenario is difficult to evaluate because we did not determine the diet composition of adult gizzard shad and abundance of bluegill and crappie was low (personal observation).

Alternatively, the initial crustacean zooplankton decline may have been due to bottom-up effects mediated by nutrients (McQueen et al. 1986). If the algal composition changed to favor inedible types, zooplankton could not graze effectively, resulting in reduced reproductive rates and biomass (Lampert 1978; Lampert et al. 1986). Once zooplankton reproductive rates were reduced, the immense predatory pressure by early juvenile gizzard shad likely could facilitate the collapse of the crustacean zooplankton population.

In Knox Lake, the late-season peak and decline of crustacean zooplankton also is not explained by young-of-year gizzard shad predation. At the time of the zooplankton peak, larval gizzard shad consumption could not accommodate daily zooplankton production; as a result, zooplankton biomass should have increased. However, the magnitude of the increase was surprising. The peak and decline of zooplankton biomass appeared to be largely the result of Diaphanosoma population dynamics. The mechanism responsible for this dramatic increase, followed by a rapid decline, is unclear. Likely explanation include a hatch of resting eggs, a change in algal composition, change in some physical factor (e.g., temperature or flow rate), and increased bacterial production (DeMott 1989).

\section{Gizzard Shad and Reservoir Community Dynamics}

Early life stages of gizzard shad may strongly influence crustacean zooplankton assemblages in Ohio reservoirs. By consuming zooplankton, gizzard shad may drive many interactions within the community. For example, gizzard shad likely influence recruitment of other fishes (Guest et al. 1990; DeVries et al. 1991). By dramatically reducing zooplankton in spring, gizzard shad larvae and early juveniles may create a competitive bottleneck through which other fishes, whose youngof-year rely on zooplankton, must recruit. Most young-of-year fishes common to Ohio reservoirs are zooplanktivorous (Siefert 1972; Michaletz et al. 1987; DeVries 1989), increasing the likelihood of such bottlenecks. Severe bottlenecks across several years likely would reduce recruitment of planktivorous sport fishes (e.g., bluegill and crappies), conceivably leading to indirect effects on community dynamics.

Gizzard shad also may influence lower trophic levels. By substantially reducing zooplankton, larval and early juvenile gizzard shad contribute to total algal biomass by removing crustacean grazers (Carpenter et al. 1987; McQueen et al. 1989) and providing nutrients through remineralization (Lazzaro et al., in press). Thus, gizzard shad may compromise water quality by increasing algal biomass.

The degree to which gizzard shad may influence community dynamics in Ohio reservoirs requires additional field tests. However, larval and especially early juvenile gizzard shad likely have the capability to strongly mediate crustacean zooplankton population dynamics within the bounds set by bottom-up processes. This capability suggests that gizzard shad, depending on zooplankton biomass and larval density, can play an important role in a larger series of reservoir community interactions than previously demonstrated.

\section{Acknowledgments}

We thank J. Miner, C. Habicht, L. Einfalt, K. Jones, and T. Wickerham, for their help in the 
field and laboratory. The comments of J. E. Breck, D. A. Culver, D. R. DeVries, and T. H. Hetherington substantially improved earlier drafts of this manuscript. This work was supported by Federal Aid in Sport Fish Restoration, Project F-57-R, administered through the Ohio Division of Wildlife. We also thank the Ohio Cooperative Fish and Wildlife Research Unit, sponsored jointly by the U.S. Fish and Wildlife Service, Ohio Department of Natural Resources, The Ohio State University, and the Wildlife Management Institute, for logistical support.

\section{References}

Adams, S. M., and D. L. DeAngelis. 1987. Indirect effects of early bass-shad interactions on predator population structure and food web dynamics. Pages 103-117 in W. C. Kerfoot and A. Sih, editors. Predation: direct and indirect impacts on aquatic communities. University Press of New England, Hanover, New Hampshire.

Balvay, P. G. 1987. Equivalence entre quelques parametres estimatifs de l'abondance du zooplancton total. Swiss Journal of Hydrobiology 49:75-84.

Barger, L. E., and R. V. Kilambi. 1980. Feeding ecology of larval shad, Dorosoma, in Beaver Reservoir, Arkansas. U.S. Fish and Wildlife Service Biological Services Program FWS/OBS-80/43:1 36-145.

Bean. D. J. 1980. Crustacean zooplankton production in Lake Erie, 1970. Master's thesis. The Ohio State University, Columbus.

Beard, T. D. 1982. Population dynamics of young-ofthe-year bluegill. Wisconsin Department of Natural Resources Technical Bulletin 127.

Bodola, A. 1966. Life history of the gizzard shad, Dorosoma cepedianum (LeSueur), in western Lake Erie. U.S. Fish and Wildlife Service Fishery Bulletin 65: $391-425$.

Carline, R. F., B. L. Johnson, and T. J. Hall. 1984. Estimation and interpretation of proportional stock density for fish populations in Ohio impoundments. North American Journal of Fisheries Management 4:139-154.

Carline, R. F., R. A. Stein, and L. M. Riley. 1986. Effects of size at stocking, season, largemouth bass predation, and forage abundance on survival of tiger muskellunge. American Fisheries Society Special Publication 15:151-167.

Carpenter, S. R., J. F. Kitchell, and J. R. Hodgson. 1985. Cascading trophic interactions and lake productivity. BioScience 35:634-639.

Carpenter, S. R., and nine coauthors. 1987. Regulation of lake primary productivity by food web structure. Ecology 68:1863-1876.

Carter, J. C. H., M. J. Dadswell, J. C. Roff, and W. G. Sprules. 1980. Distribution and zoogeography of planktonic crustaceans and dipterans in glaciated eastern North America. Canadian Journal of Zoology 58:1355-1387.
Chesson, J. 1978. Measuring preference in selective predation. Ecology 59:211-215.

Chesson, J. 1983. The estimation and analysis of preference and its relationship to foraging models. Ecology 64:1297-1304.

Cochran, P. A., and I. R. Adelman. 1982. Seasonal aspects of daily ration and diet of largemouth bass, Micropterus salmoides, with an evaluation of gastric evacuation rates. Environmental Biology of Fishes 7:265-275.

Cramer, J. D., and G. R. Marzolf. 1970. Selective predation on zooplankton by gizzard shad. Transactions of the American Fisheries Society 99:320-332.

Culver, D. A., M. M. Boucherle, D. J. Bean, and J. W. Fletcher. 1985. Biomass of freshwater crustacean zooplankton from length-weight regressions. Canadian Journal of Fisheries and Aquatic Sciences 42:1380-1390.

Culver, D. A., and W. R. DeMott. 1978. Production of zooplankton at nearshore stations in Lakes Ontario and Erie. Internationale Vereinigung fir theoretische und angewandte Limnologie Verhandlungen 20:252-256.

Dabrowski, K., E. Murawska, J. Terlecki, and S. Wielgosz. 1984. Studies on the feeding of Coregonus pollan (Thompson) alevins and fry in Lough Neagh. Internationale Revue der Gesamten Hydrobiologie 69:529-540.

DeMott, W. R. 1989. The role of competition in zooplankton succession. Pages 195-252 in U. Somer, editor. Plankton ecology. Springer-Verlag, New York.

DeVries, D. R., and R. A. Stein. 1990. Manipulating shad to enhance sport fisheries in North America: an assessment. North American Journal of Fisheries Management 10:209-223.

DeVries, D. R., and R. A. Stein. 1992. Complex interactions between fish and zooplankton: quantifying the role of an open-water planktivore. Canadian Journal of Fisheries and Aquatic Sciences 49:12161227.

DeVries, D. R., R. A. Stein, J. G. Miner, and G. G. Mittelbach. 1991. Stocking threadfin shad: consequences for young-of-year fishes. Transactions of the American Fisheries Society 120:368-381.

Drenner, R. W., and S. R. McComas. 1980. The roles of zooplankter escape ability and fish size selectivity in the selective feeding and impact of planktivorous fish. Pages 587-593 in W. C. Kerfoot, editor. Evolution and ecology of zooplankton communities. University Press of New England, Hanover, New Hampshire.

Drenner, R. W., W. J. O'Brien, and J. R. Mummert. 1982a. Filter-feeding rates of gizzard shad. Transactions of the American Fisheries Society 111:210 215.

Drenner, R. W., F. DeNoyelles, Jr., and D. Kettle. 1982b. Selective impact of filter-feeding gizzard shad on zooplankton community structure. Limnology and Oceanography 27:965-968.

Drenner, R. W., J. R. Strickler, and W. J. O'Brien. 1978. Capture probability: the role of zooplankter escape 
in the selective feeding of planktivorous fish. Journal of the Fisheries Research Board of Canada 35: 1370-1373.

Elliott, J. M., and L. Persson. 1978. The estimation of daily rates of food consumption for fish. Journal of Animal Ecology 47:977-991.

Guest, W. C., R. W. Drenner, S. T. Threlkeld, F. D. Martin, and J. D. Smith. 1990. Effects of gizzard shad and threadfin shad on zooplankton and youngof-year white crappie production. Transactions of the American Fisheries Society 119:529-536.

Gulyas, P. 1980. The effect of temperature on the most frequent Cladocera and Copepoda species in Lake Velence. Aquacultura Hungarica 2:2155-2170.

Hall, D. J., and T. J. Ehlinger. 1989. Perturbation, planktivory, and pelagic community structure: the consequence of winterkill in a small lake. Canadian Journal of Fisheries and Aquatic Sciences 46:22032209.

Haney, J. F., and D. J. Hall. 1973. Sugar-coated Daphnia: a preservation technique for Cladocera. Limnology and Oceanography 18:331-333.

Hunter, J. R., and C. A. Kimbrell. 1980. Early life history of Pacific mackerel. Scomber japonicus. U.S. National Marine Fisheries Service Fishery Bulletin 78:89-101.

Johnson, B. M., R. A. Stein, and R. F. Carline. 1988. Use of a quadrat rotenone technique and bioenergetics modeling to evaluate prey availability to stocked piscivores. Transactions of the American Fisheries Society 117:127-141.

Keast. A. 1980. Food and feeding relationships of young fish in the first weeks after the beginning of exogenous feeding in Lake Opinicon, Ontario. Environmental Biology of Fishes 5:305-314.

Kutkuhn, J. H. 1958. Utilization of plankton by gizzard shad in a shallow prairie lake. Transactions of the American Fisheries Society 87:80-103.

Lampert. W. 1978. A field study on the dependence of fecundity of Daphnia spec. on food concentration. Oecologia (Berlin) 36:363-369.

Lampert. W., W. Fleckner, H. Rai, and B. E. Taylor. 1986. Phytoplankton control by grazing zooplankton: a study on the spring clear-water phase. Limnology and Oceanography $31: 478-490$.

Lazzaro. X. L., R. W. Drenner, R. A. Stein, and J. D. Smith. In press. Planktivores and plankton dynamics: effects of fish biomass and planktivore type. Canadian Journal of Fisheries and Aquatic Sciences.

Mallin, M. A., L. J. Birchfield, and W. Warren-Hicks. 1987. Food habits and diet overlap of larval Lepomis spp. and gizzard shad in a Piedmont reservoir. Proceedings of the Annual Conference Southeastern Association of Fish and Wildlife Agencies 39(1985):146-155.

Matthews, W. J., L. G. Hill, D. R. Edds, J. J. Hoover, and T. G. Heger. 1988. Trophic ecology of striped bass, Morone saxatilis, in a freshwater reservoir (Lake Texoma. U.S.A.). Journal of Fish Biology 33: 273-288.

McQueen, D. J., M. R. Johannes, J. R. Post, T. J. Stew- art. and D. R. S. Lean. 1989. Bottom-up and topdown impacts on freshwater pelagic community structure. Ecological Monographs 59:289-309.

McQueen, D. J., J. R. Post, and E. L. Mills. 1986. Trophic relationships in freshwater pelagic ecosystems. Canadian Journal of Fisheries and Aquatic Sciences 43: 1571-1581.

Michaletz, P. H., D. G. Unkenholz, and C. C. Stone. 1987. Prey size selectivity and food partitioning among zooplanktivorous age- 0 fishes in Lake Francis Case, South Dakota. American Midland Naturalist 117:126-139.

Miller, R. R. 1960. Systematics and biology of the gizzard shad (Dorosoma cepedianum) and related fishes. U.S. Fish and Wildlife Service Fishery Bulletin 173:371-392.

Mills, E. L., and J. L. Forney. 1981. Energetics, food consumption, and growth of young yellow perch in Oneida Lake, New York. Transactions of the American Fisheries Society 1 10:479-488.

Mills, E. L., J. L. Forney, and K. J. Wagner. 1987. Fish predation and its cascading effect on the Oneida Lake food chain. Pages 118-131 in W. C. Kerfoot and $A$. Sih, editors. Predation: direct and indirect impacts on aquatic communities. University Press of New England, Hanover, New Hampshire.

Murdoch. W. W., and J. Bence. 1987. General predators and unstable prey populations. Pages 17-30 in W. C. Kerfoot and A. Sih, editors. Predation: direct and indirect impacts on aquatic communities. University Press of New England, Hanover, New Hampshire.

Nero, R. W., and W. G. Sprules. 1986. Predation by three glacial opportunists on natural zooplankton communities. Canadian Journal of Zoology 64:5764.

Noble, R. L. 1981. Management of forage fishes in impoundments of the southern United States. Transactions of the American Fisheries Society 110 : 738-750.

O'Brien. W. J. 1987. Planktivory by freshwater fish: thrust and parry in the pelagia. Pages 3-16 in W. C. Kerfoot and A. Sih, editors. Predation: direct and indirect impacts on aquatic communities. University Press of New England, Hanover. New Hampshire.

Persson, L. 1979. The effects of temperature and different food organisms on the rate of gastric evacuation in perch (Perca fluviatilis). Freshwater Biology 9:99-104.

Persson, L. 1982. Rate of food evacuation in roach (Rutilus rutilus) in relation to temperature, and the application of evacuation rate estimates for studies on the rate of food consumption. Freshwater Biology 12:203-210.

Peters, R. H. 1983. The ecological implications of body size. Cambridge University Press, New York.

Pierce, R. J. 1977. Life history and ecological energetics of the gizzard shad (Dorosoma cepedianum) in Acton Lake, Ohio. Doctoral dissertation. Miami University, Oxford, Ohio.

Pierce, R. J., T. E. Wissing, and B. A. Megrey. 1981. 
Aspects of the feeding ecology of gizzard shad in Acton Lake, Ohio. Transactions of the American Fisheries Society 110:391-395.

Plante, C., and J. A. Downing. 1989. Production of freshwater invertebrate populations in lakes. Canadian Journal of Fisheries and Aquatic Sciences 46:1489-1498.

Post, J. R., and D. J. McQueen. 1988. Ontogenetic changes in the distribution of larval and juvenile yellow perch (Perca flavescens): a response to prey or predators? Canadian Joumal of Fisheries and Aquatic Sciences 45:1820-1826.

Rajasilta, M., and I. Vuorinen. 1983. A field study of prey selection in planktivorous fish larvae. Oecologia (Berlin) 59:65-68.

Scavia. D., G. A. Lang, and J. F. Kitchell. 1988. Dynamics of Lake Michigan plankton: a model evaluation of nutrient loading, competition, and predation. Canadian Journal of Fisheries and Aquatic Sciences 45:165-177.

Siefert, R. E. 1972. First food of larval yellow perch, white sucker, bluegill, emerald shiner, and rainbow smelt. Transactions of the American Fisheries Society 101:219-225.
Stein, R. A., and seven coauthors. 1988. Size-structured interactions in lake communities. Pages 161 179 in S. R. Carpenter, editor. Complex interactions in lake communities. Springer-Verlag, New York.

Van Den Avyle, M. J., and J. R. Wilson. 1980. Food habits and feeding selectivity of larval Dorosoma spp. in Center Hill Reservoir. U.S. Fish and Wildlife Service FWS/OBS-80/43:146-156.

Wahl, D. H., and R. A. Stein. 1988. Selective predation by three esocids: the role of prey behavior and morphology. Transactions of the American Fisheries Society 117:142-151.

Webb, D. G., and T. R. Parsons. 1988. Empirical analysis of the effect of temperature on marine harpacticoid copepod development time. Canadian Journal of Zoology 66:1376-1381.

Werner, E. E., and J. F. Gilliam. 1984. The ontogenetic niche and species interactions in size-structured populations. Annual Review of Ecology and Systematics 15:393-425.

Received May 3, 1991

Accepted November 19, 1991 